\title{
Middle Permian (Late Murgabian) Fusulinids of the Jamal Formation, Tabas Area, Iran
}

\author{
H. Yarahmadzahi ${ }^{a,}$ * and E. Ja. Leven ${ }^{b, * *}$ \\ ${ }^{a}$ Department of Geology, Earth Sciences Research Center, Zahedan Branch, Islamic Azad University, Zahedan, Iran \\ ${ }^{b}$ Geological Institute, Russian Academy of Sciences, Moscow, 119017 Russia \\ *e-mail: Hamed.yarahmadzahi@gmail.com \\ **e-mail: erleven@yandex.ru
}

Received October 7, 2020; revised February 25, 2021; accepted April 14, 2021

\begin{abstract}
Numerous fusulinids were found in the middle part of the Jamal Formation (Ney Eshkiny section) in the Tabas region of Central Iran. The assemblage includes 12 species of 12 genera (Zarodella, ?Grovesella, Pseudoendothyra, Nankinella, Schubertella, Dunbarula, Yangchienia, Chusenella, Verbeekina, Pseudodoliolina, Neoschwagerina, and Sumatrina. This association characteristic of the upper part of the Murgabian Stage is found in many Permian sections in the Tethyan Realm.
\end{abstract}

Keywords: stratigraphy, fusulinids, Permian, Murgabian Stage, Iran, Tabas, Jamal Formation

DOI: $10.1134 / \mathrm{S} 0869593821050075$

\section{INTRODUCTION}

The territory of Iran is geologically heterogeneous and is subdivided into several large tectonic blocks (Fig. 1). Most of them contain Permian deposits, somewhat differing both lithologically and in the fossil content. Despite these differences, in all blocks, the Upper Carboniferous-Permian succession is distinctly subdivided into two large depositional cycles, the Gzhelian-Asselian (Sakmarian?) and Bolorian-Dorashamian. Fusulinids characteristic of the Gzhelian, Asselian, and Bolorian beds are relatively similar in all blocks where deposits of this age are found. This indicates the close conditions that existed at this time throughout Iran and the free connections between the basins. The geological situation changed at the end of the Kubergandian time. Thus, in the southern blocks (SanandajSirjan and Zagros), the sediments of the Murgabian Stage contain abundant and diverse fusulinids, of which specimens of Eopolydiexodina (Davydov and Arefifard, 2013; Kobayashi and Ishii, 2003) are especially prolific. To the north, in Central Iran and Alborz, Murgabian fusulinids are extremely rare. To date, only isolated fusulinid occurrences are known from there, with no Eopolydiexodina present. Therefore, the discovery of a rich assemblage of Murgabian fusulinids is of undoubted interest both for geological correlations and for recognition of connections between basins of the northern and southern regions of Iran.

\section{MATERIALS AND METHODS}

The research whose results are presented in this paper focused on the north of the Tabas block of Cen- tral Iran. At the Ney Eshkiny locality, located $5 \mathrm{~km}$ northeast of the village of Kharv and $22 \mathrm{~km}$ east of Tabas $\left(33^{\circ} 99^{\prime} 36^{\prime \prime} \mathrm{N}, 57^{\circ} 10^{\prime} 44^{\prime \prime} \mathrm{E}\right)$, the middle part of the Jamal Formation was studied; 30 samples were collected, from which 140 oriented thin sections were made. The Levitz Wetzlar microscope and the Superior Statistical Analysis Pro (version 9/0 LIMPED 2008) were used for study and photography. Samples and thin sections are housed at the Geosciences Research Center of the Islamic Azad University, Zahedan, Iran (collection nos. 1-30).

\section{GEOLOGICAL SETTING}

The Permian deposits within the Tabas block are well developed and studied to the north (Ozbak-Kuh and Shirgesht Mountains) and east (Shotori Range) of the city of Tabas. The lowermost beds of the Permian section are found only in the northernmost regions (the Ozbak-Kuh Mountains), where they constitute part of the Zaladou Formation, characterized by Gzhelian and Asselian fusulinids. Overlying dolomites of the Tighe-Maadanou Formation, probably of Sakmarian age, are overlain by Jurassic sandstones (Leven and Taheri, 2003). To the south, in the Shirgesht and Shotori mountains, there are no outcrops of the lower stages of the Permian. The Permian sediments, represented mainly by limestones and dolomites (300-600 m), are unconformably deposited here on sandstones and shales of the Sardar Carboniferous series (Stöcklin et al., 1965). This stratum of carbonate rocks was isolated by the Stockline in the Jamal Formation. He assigned it to the Upper Perm- 


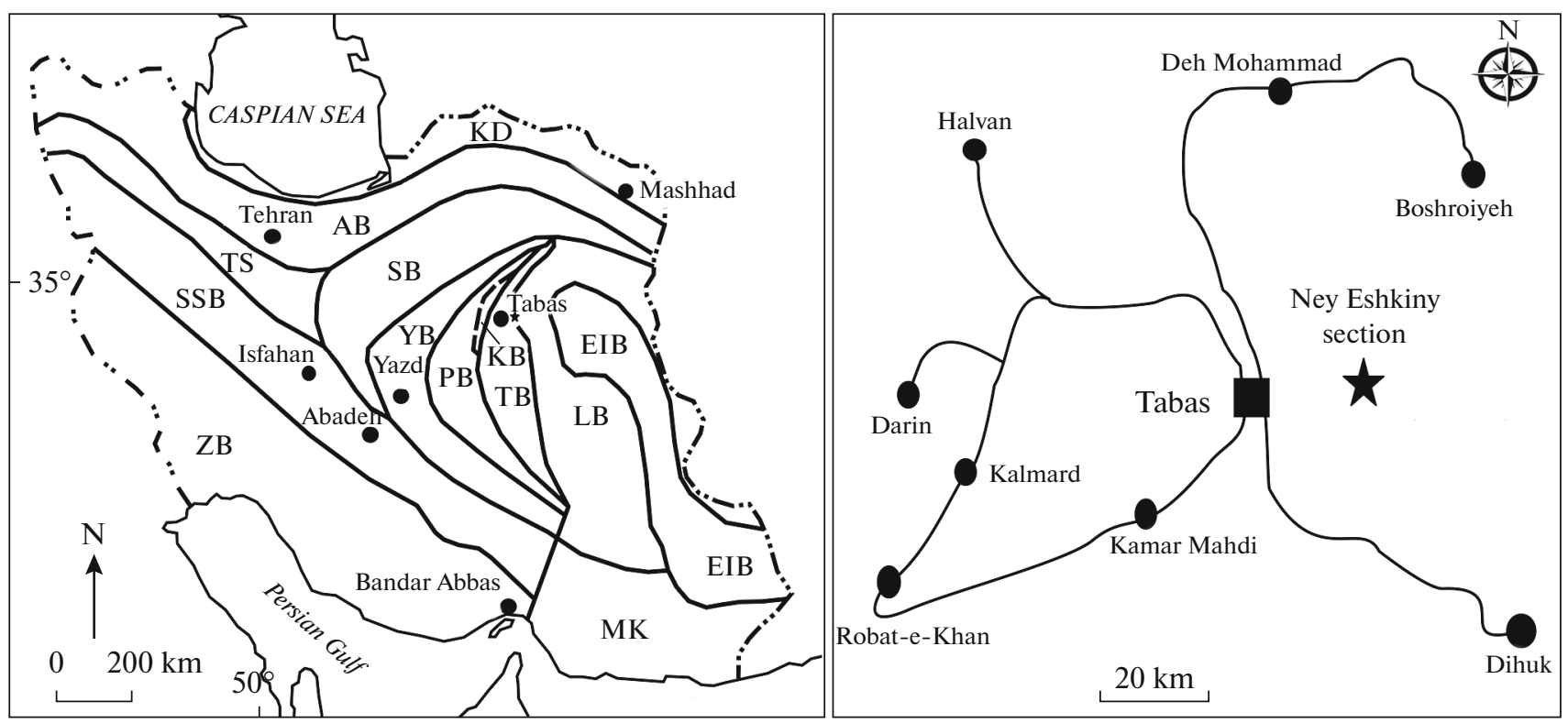

Fig. 1. Location of the Ney Eshkiny section. Tectonic blocks: KD-Kopetdag, AB-Alborz, TS-Tabriz-Sevekh, SB-Sabzavar, YB-Yazd, PB-Posh Bedam, KB-Kalmard, TB-Tabas, LB-Lut, EIB-East Iranian, SSB-Sanandaj Sirjan, ZB-Zagros, MK-Makran.

ian, although he noted that, in the Shirgesht Mountains to the north of Tabas, at its base, there are foraminifers and ammonoids characteristic of the upper part of the Lower Permian (Stöcklin, 1971). Partoazar (1995) separated this part of the succession into an independent Bage-Vang Formation, assuming its age to be Asselian-Sakmarian. However, later numerous fusulinid and conodont occurrences (Leven and Vaziri Mohaddam, 2004) made it possible to redefine the age of this formation as Bolorian-early Kubergandian, which confirmed Stöcklin's data. Accordingly, the lower boundary of the overlying Jamal Formation in the Shirgesht Mountains to the north of Tabas lies within the Kubergandian. Taking into account occurrences of the Murgabian Neoschwagerina and Sumatria in the middle part of the formation and the Julfian-Dorashamian Reichelina, Paradoxiella, and Colaniella near its top, the formation was dated as late Kubergandian-Dorashamian (Leven and Vaziri Mohaddam, 2004). The age of the Jamal Formation in the Sotori Mountains to the south, where it was first established by Stöcklin, is less certain. Bolorian Misellina was found at the base of the formation (Leven and Gorgij, 2011), which allows this part of the section to be correlated with the Bage-Vang Formation from more northern areas. The higher parts of the section of the Jamal Formation provide virtually no data on the presence of age-determining fusulinids, except for a reference to a finding of a Murgabian Verbeekina (Bozorgnia, 1964), as well as Misellina sp., Neoschwagerina schuberti, N.? margaritae, and Pseudodoliolina (Jenny Deshusses, 1983). However, judging by the photographs in the above-cited work, the first two taxa from this list resemble Cancellina pamirica from the upper Kubergandian of the southeastern Pamir (Leven, 1967). No images of the remaining two taxa were provided, so their presence in the section remains questionable. In the section studied, the Jamal Formation is represented by its middle part, composed of dark gray medium- and coarse-bedded limestones with small interbeds of dolomite (Fig. 2). Approximately $30 \mathrm{~m}$ of the section contain fusulinids, among which shells of Verbeekina prevail, in places extremely abundant.

\section{FUSULINIDS}

The middle part of the studied section contains the following fusulinids: Zarodella sp., Grovesella? sp., Pseudoendothyra sp., Nankinella cf. kuzuensis Igo et Igo, Schubertella giraudi (Deprat), Sch. simplex Lange, Sch. ex gr. kingi Dunbar et Skinner, Sch. ? minatisphaera Kobayashi, Sch. ? karasawensis Kobayashi, Dunbarula aff. schubertellaeformis Sheng, Yangchienia cf. compressa (Ozawa), Chusenella ? sp., Verbeekina verbeeki (Geinitz), V. heimi Thompson et Foster, Neoschwagerina cf. colaniae Ozawa, Neoschwagerina sp., Sumatrina sp., Pseudodoliolina pseudolepida (Deprat) (Plates I-III).

The most numerous are representatives of the genus Verbeekina, which in places are extremely abundant (Beds 23 and 26). They belong to two closely related species, $V$. verbeeki and $V$. heimi, differing only in the more or less close coiling of the shell spiral. Both species are widespread within the Tethyan Realm, where they are confined mainly to the upper part of 


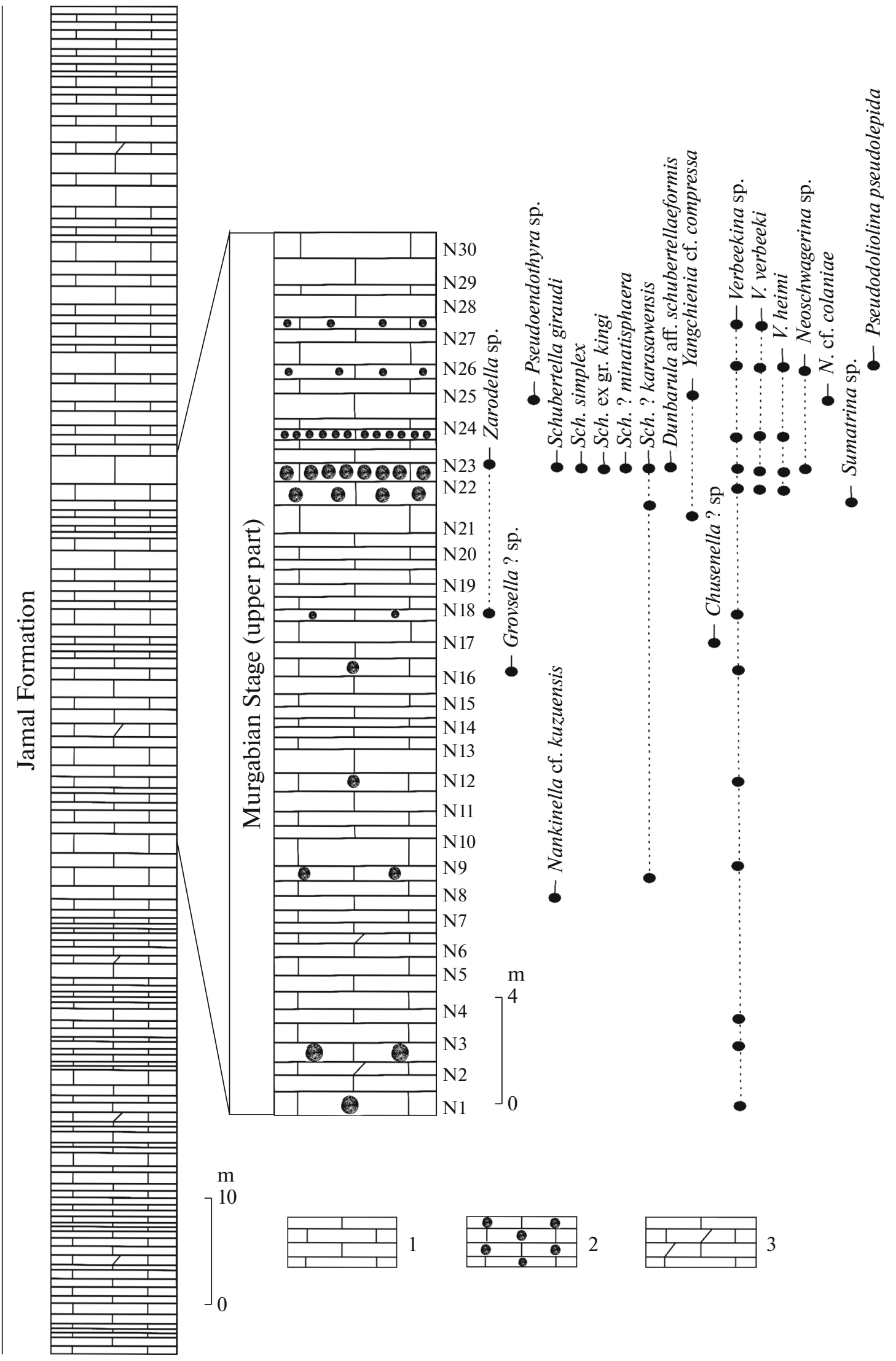

Fig. 2. Distribution of fusulinids in the Ney Eshkiny section. (1) Limestones, (2) Verbeekina limestones, (3) dolomitized limestones. 
the Murgabian but can also continue into the Midian. In Iran, $V$. heimi was described from the Afghanella schencki Zone of the Abadeh section, which is recognized there as part of the Murgabian Stage (Kobayashi and Ishii, 2003).

Other genera of derived fusulinids, which, unfortunately, are very low in number, are important for dating the beds of the section. These include Neoschwagerina, Sumatrina, and Psedodoliolina.

The genus Neoschwagerina is represented by four specimens, two of which cannot be identified to species, while two are close to $N$. colaniae Ozawa. This species is known from a number of sections in China, Indochina, and Japan, where it is confined to beds approximately corresponding to the middle and upper parts of the Murgabian Stage. In the Jamal Formation, Neoschwagerina were previously found in the Shirgesht Mountains (Tabas block) (Leven and Vaziri Mohaddam, 2004). There is evidence of their findings in the Ruteh Formation of Alborz (Bozorgnia, 1973; Lys et al., 1978; Vaziri, 2008; Vaziri et al., 2005). However, in cases where these data are illustrated by photographs, it is clear that the Kubergandian Armenina (Lys et al.) or Misellina (?) (Bozorgnia) were mistakenly identified as Murgabian Neoschwagerina. Neoschwagerina is well represented in the Abadeh section of the Sanandaj Sirjan block, where they are confined to the N. margaritae Zone (Baghbani, 1993). Later, Kobayashi and Ishii (2003) limited the distribution of Neoschwagerina to the $\mathrm{N}$. occidentalis Zone, which corresponds to the upper part of the N. margaritae Zone in Baghbani's scheme and is located between the Beds with Eopolydiexodina and Afghanella (below) and Beds with Chusenella abichi (above).

The genus Sumatrina is present in our material in the form of two oblique sections, which does not permit identification to species. Judging by the shell shape and the number of secondary septula, it can be assumed that these sections belong to $S$. annae Volz, but there is no certainty about this. Sumatrina appear in the middle part of the Murgabian Stage and continue to the Midian. In Iran, Sumatrina ( $S$. annae) were described from the Abadeh section, where they were found in the upper part of the Murgabian Stage and the lower part of the Midian Stage (Ch. abichi Zone) (Kobayashi and Ishii, 2003). A single representative of the genus was also found in the middle part of the Jamal Formation in the Bage-Vang section of Central Iran (Leven and Vaziri Mohaddam, 2004).

The genus Pseudodoliolina is represented in the collection studied by a single specimen, with all characters of $P$. pseudolepida (Deprat). This species is widespread within the Tethyan Realm in beds approximately corresponding to the upper part of the Murgabian Stage and the base of the Midian. In Iran, undetermined representatives of the genus Pseudodoliolina are known in the Abadeh section in the A. schencki and $\mathrm{N}$. occidentalis zones, i.e., from the upper half of the Murgabian Stage (Kobayashi and Ishii, 2003).

Representatives of the order Schubertellida play a significant role in the studied material. Primarily, these are species of the genus Schubertella, such as Sch. giraudi (Deprat), Sch. simplex Lange, and some others known from many sections of the Murgabian Stage. The genus Dunbarula is represented by a single specimen resembling D. schubertellaeformis Sheng from the Maokou Formation of Northwestern China, where it is associated with Verbeekina and Neoschwagerina (Sheng, 1958). The few representatives of the genus Yangchienia most likely belong to $Y$. compressa (Ozawa). This species and species close to it in level of development are widespread and characteristic of the upper part of the Murgabian Stage. Of interest is the presence in the material under consideration of the primitive genera Zarodella and Grovesella, which previously were not found above the Bolorian Stage (Leven, 2010).

Summing up, we can confidently state that the considered association of fusulinids is typical of the upper part of the Murgabian Stage of the Tethyan scale. Although some species and genera can continue to the Midian stage, no typical representatives of fusulinids of this stage were found in our material.

\section{CORRELATION AND AGE}

The above discussion shows that the fusulinid beds of the Ney Eshkiny section have equivalents in some other sections of the Permian of Iran. Within the Tabas block, these are the Neoschwagerina and Sumatrina Beds from the middle part of the Jamal Formation in the Shirgesht Mountains (Leven and Vaziri Mohaddam, 2004). In the Sanandaj Sirjan block, these beds correspond to the N. occidentalis Zone and, possibly, the upper part of the underlying

Plate I. Fusulinids from the Ney Eshkiny section; $(26-28) \times 10$ (scale bar D = $0.5 \mathrm{~mm}) ;(19,20) \times 20(\mathrm{scale}$ bar C=0.5 mm); $(21-23) \times 30$ (scale bar B $=0.5 \mathrm{~mm}),(1-18,24$, and 25$) \times 50$ (scale bar A $=0.5 \mathrm{~mm}) ;(1,2)$ Zarodella sp., axial sections, Samples 19 and 24, respectively; (3) ?Grovesella sp., axial section, Sample 17; (4, 6) Schubertella giraudi (Deprat), axial sections, Sample 24; (5) Schubertella ? minatisphera Kobayashi, axial section, Sample 24; (7-12) Schubertella simplex Lange, subaxial sections, Sample 24; $(13,14)$ Schubertella sp., axial sections, Sample 10; $(15-17)$ Schubertella? karasawensis Kobayashi, subaxial sections, Samples 24, 10, and 23, respectively; (18) Dunbarula aff. schubertellaeformis Sheng, axial section, Sample 24; (19) Nankinella cf. kuzuensis Igo et Igo, subaxial section, Sample 9; (20) Pseudoendothyra sp., axial section, Sample 26; (21-23) Yangchienia cf. compressa (Ozawa), subaxial sections, Samples 26, 22, and 26, respectively; (24, 25) Schubertella ex gr. kingi Dunbar et Skinner, axial sections, Sample 24; (26) Neoschwagerina cf. colaniae Ozawa, tangential, slightly oblique section, Sample 26; $(27,28)$ Neoschwagerina sp., median and tangential oblique sections, Samples 24 and 26, respectively. 


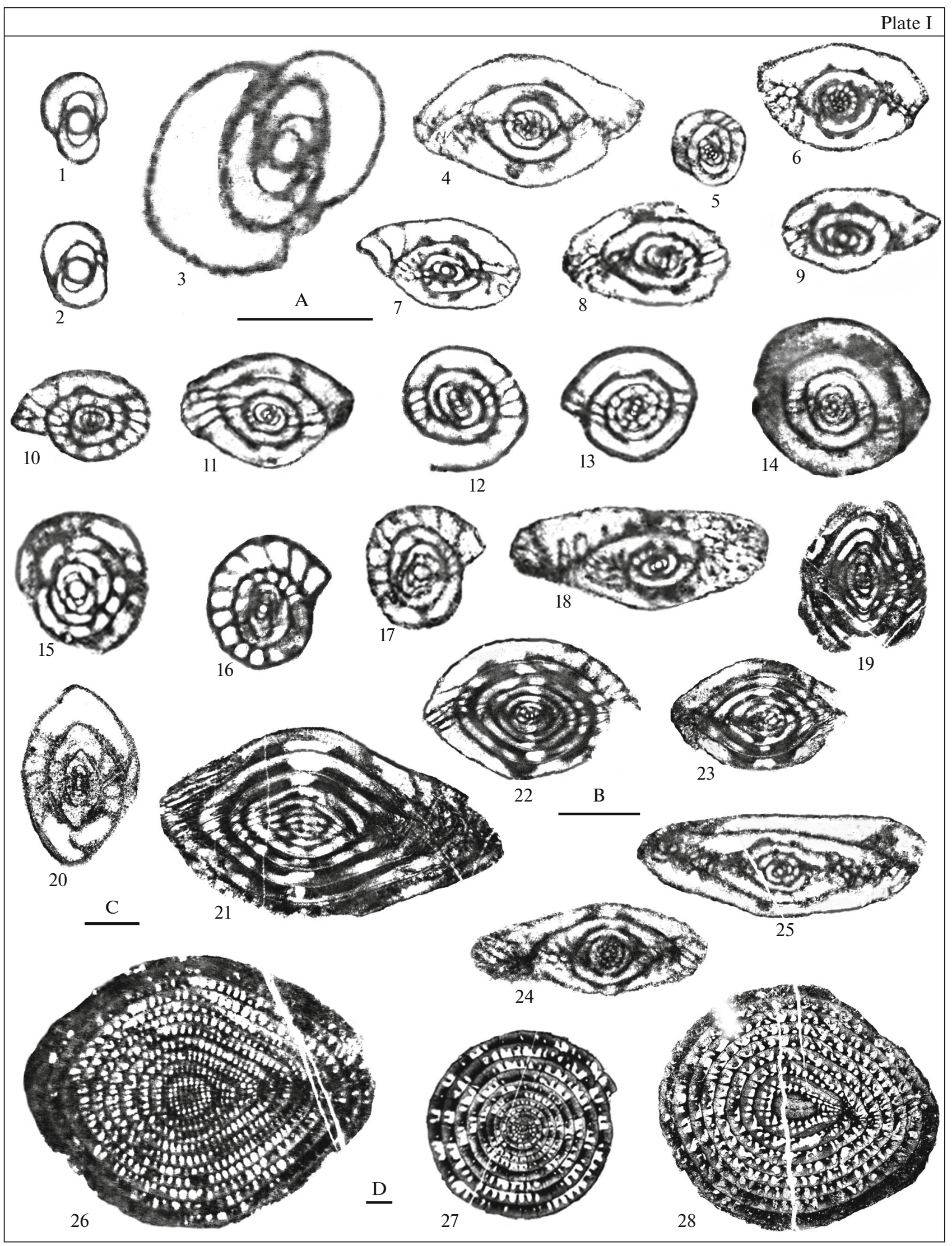




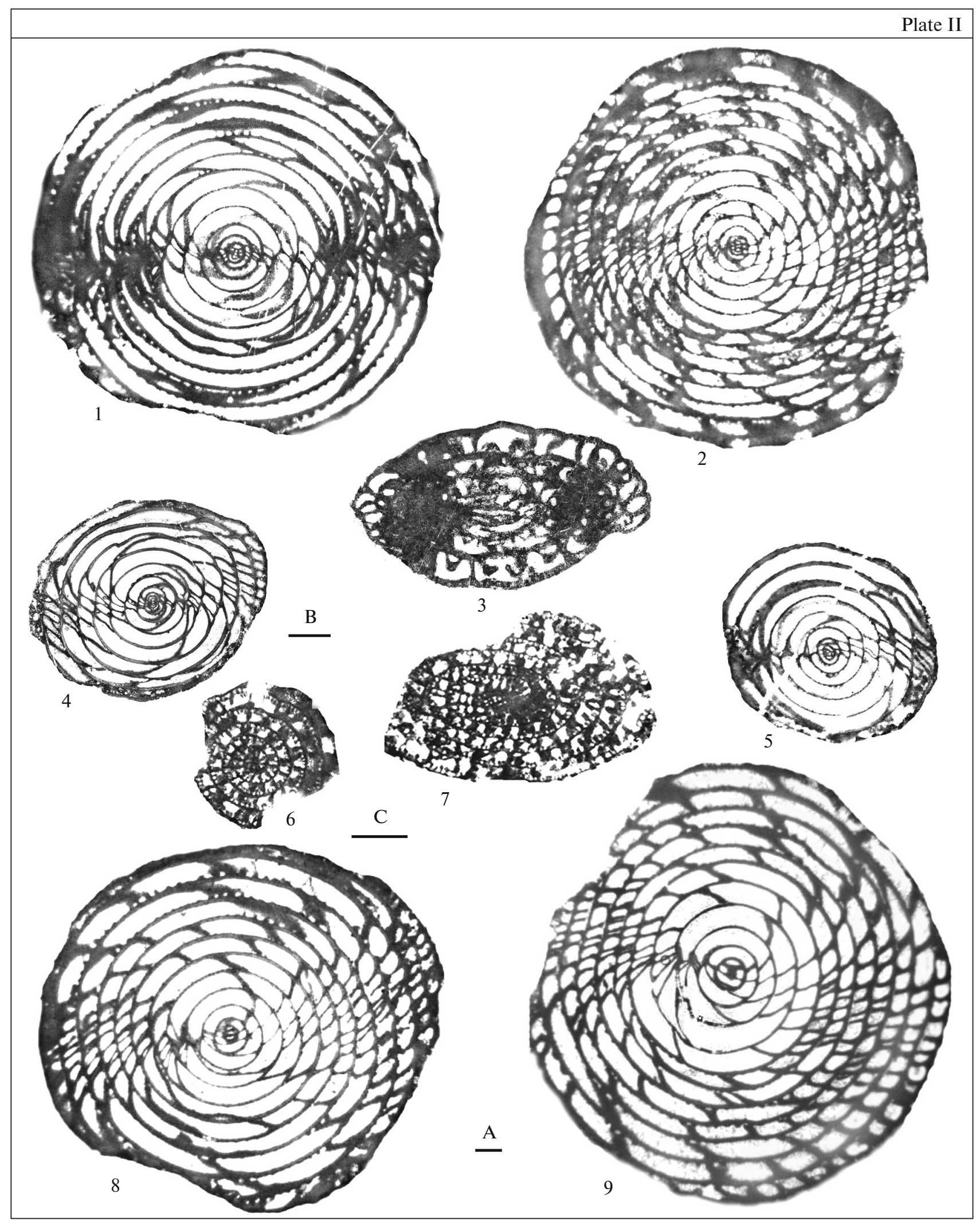

Plate II. Fusulinids from the Ney Eskiny section; $(1,2,4,5,8,9) \times 10$ (scale bar A $=0.5 \mathrm{~mm}) ;(3) \times 15$ (scale bar B = $0.5 \mathrm{~mm})$ and $(6,7) \times 20$ (scale bar $\mathrm{C}=0.5 \mathrm{~mm}) ;(1,2,4,5,8,9)$ Verbeekina verbeeki (Geinitz): (1) axial section, Sample $24 ;(2,8,9)$ subaxial sections, Sample 24; $(4,5)$ subaxial sections of juvenile specimens, Sample 23; (3) Chusenella ? sp., subaxial section, Sample 18; $(6,7)$ Sumatrina sp., oblique section, Sample 23. 


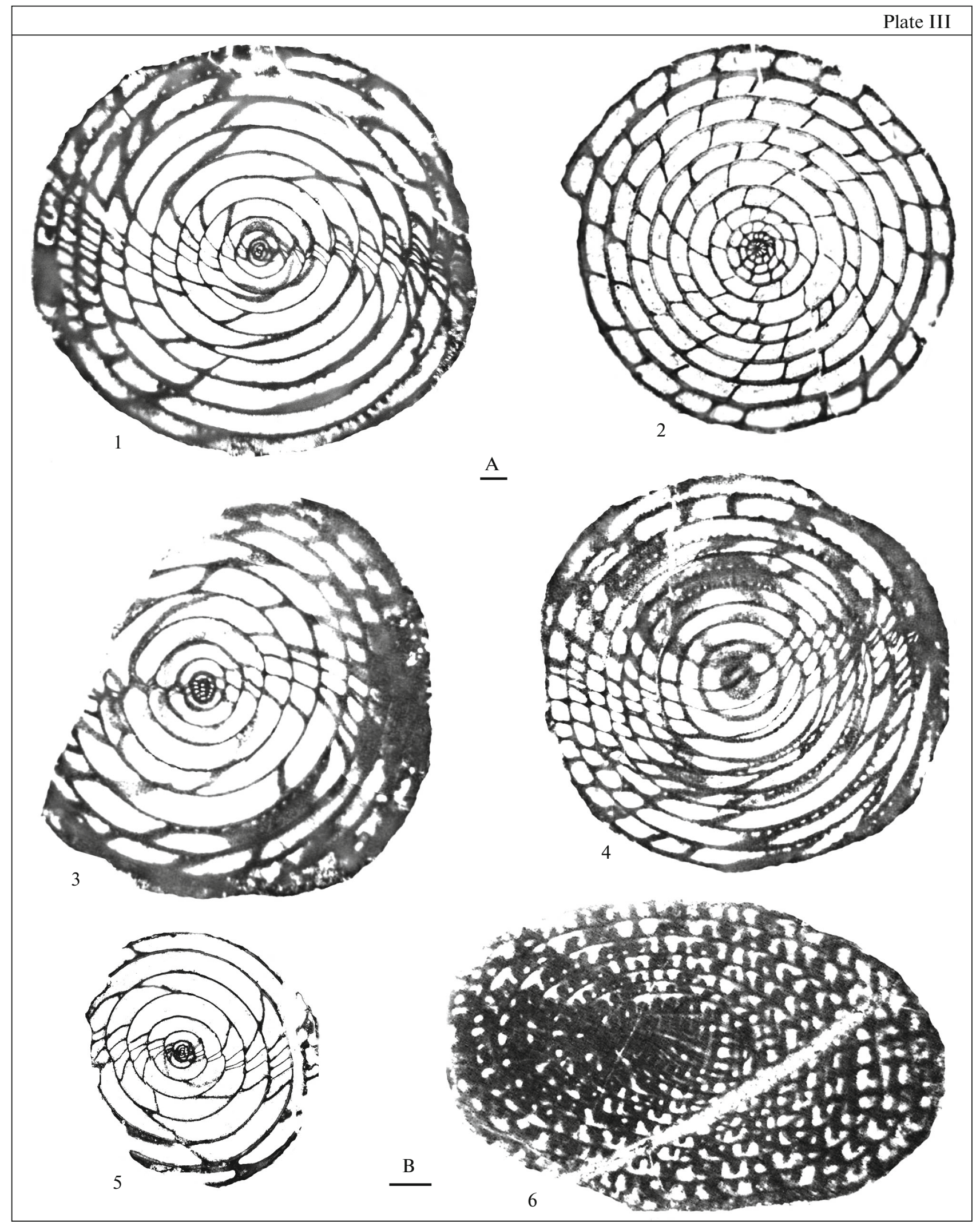

Plate III. Fusulinids from the Ney Eskiny section; $(1-5) \times 10$ (scale bar $=0.5 \mathrm{~mm})$ and $(6) \times 15$ (scale bar $=0.5 \mathrm{~mm}) ;(1-5)$ Verbeekina heimi Thompson et Foster: (1) subaxial section, Sample 23; (2) median section, Sample 23; (3) subaxial section, Sample 23; (4) tangential section, Sample 23; (5) subaxial section of a juvenile specimen, Sample 26; (6) Pseudodoliolina pseudolepida (Deprat), oblique section, Sample 27. 
A. shencki Zone (Kobayashi and Ishii, 2003). Outside Iran, the Verbeekina-Neoschwagerina Beds are found in many sections of the Tethyan Realm, especially in its eastern regions.

In Afghanistan, at the well-known fusulinid localities of Khojagor and Bulola, the beds under consideration correspond to the lower part of the massive limestone sequence (Bed F) with Sumatrina and highly organized Neoschwagerina. As in the Abadeh section of Iran, Beds with Afghanella and numerous Eopolydiexodina lie below (Leven, 1997).

In the Southeastern Pamir, in the typical section of the Murgabian Stage (Jamantal Mountain), the beds under consideration correspond approximately to a stratum of limestones and siliceous shales (Deire Beds of the Gan Formation) with rare Neoschwagerina, Verbeekina, and Yangchienia. They overlap the so-called Jamantal Beds with early Murgabian Neoschwagerina, Praesumatrina, and Afghanella and, in turn, are replaced by detrital limestones (Karasu Beds) with Yabeina of Midian age (Leven, 1967).

In the longline scale developed from the sections of South China, the fusulinid beds of the Ney Eshkiny section approximately correspond to the upper part of the Kuhfengian Stage or the Neoschwagerina margaritae Zone (Sheng and Jin, 1994). This zone is distinguished in many sections and contains most of the genera and species characteristic of beds of similar age. The Permian section of the Baoshan block (Yunnan province) does not fit into the standard Chinese tier scale. According to many researchers, this block is a fragment of Gondwana that migrated from cold high latitudes to low, subtropical and tropical latitudes during the Permian Period (Huang et al., 2015, 2020). The position of this block, isolated with respect to the main territory of China, is reflected in the character of the fusulinid biota. As an example, we can cite the presence of Eopolydiexodina in the sections of the Baoshan block, which have not yet been noted in southern China, but are characteristic of the sections of southern Iran (Zagros and Sanandaj Sirjan block). The beds under consideration at the Ney Eshkiny locality in the section of the Baoshan block correspond to beds with a similar composition of the fusulinid assemblage, which, as in the Iranian assemblage, contains various Verbeekina, as well as Pseudodoliolina, Sumatrina, Yangchienia, etc. The similarity is emphasized by the abundance of Verbeekina, as in the section Ney Eshkiny, in places overflowing the enclosing rock. This similarity leaves no doubt that the compared beds are of the same age, in our opinion, late Murgabian. This does not coincide with the opinion of the Chinese experts, who consider them to be younger, i.e., Midian. However, typically mussel fusulinids, such as Yabeina, Lepidolina, and a number of others, are not recorded in the Verbeekina Beds of the Baoshan block. The genera and species present in them are characteris- tic of the Murgabian Stage, although some of them can also occur in the Midian Stage.

In the most complete Permian sections of Japan (Akioshi, Akasaka, Kanto, etc.), the upper part of the Murgabian Stage is represented by beds with highly developed Neoschwagerina, such as $N$. margaritae, $N$. colaniae, and $N$. haydeni. They are separated into an independent zone, in which, along with Neoschwagerina, Verbeekina, Sumatrina, and other genera and species characteristic of the corresponding beds of the Ney Eshkiny section are usually present. All this leaves no doubt that the compared beds of Japan and Iran are of the same age.

\section{CONCLUSIONS}

(1) For the first time, a rich fusulinid assemblage (12 genera and 12 species) was discovered and described in the Jamal Formation of the Tabas block. This allows for reliable dating and correlation of the corresponding part of the formation with other sections both in Iran and many sections of the Tethyan Region, from Afghanistan in the west to Japan in the east.

(2) The similarity of the late Murgabian fusulinid assemblages traced over a large area indicates free connections of the basin where the Jamal Formation was deposited to other Tethyan basins, including the basins located within the Sanandaj Sirjan and Zagros blocks. The latter is of interest because the previously mentioned basins of southern Iran were probably isolated from those located to the north. This is evidenced by the almost complete absence of fusulinids in the sections of most of the Murgabian Stage of Central and Northern Iran, while to the south they are abundant and diverse.

\section{ACKNOWLEDGMENTS}

We are grateful to Ehsan Ajoodani-Feizabad and Ehsan Zamanian for their help during field work and collecting material analyzed in this study.

\section{FUNDING}

Financial support was provided by Islamic Azad University, Zahedan Branch (no. 14-11-1-380).

Reviewers S.V. Naugolnykh and T.V. Filimonova

\section{OPEN ACCESS}

This article is licensed under a Creative Commons Attribution 4.0 International License, which permits use, sharing, adaptation, distribution and reproduction in any medium or format, as long as you give appropriate credit to the original author(s) and the source, provide a link to the Creative Commons license, and indicate if changes were made. The images or other third party material in this article are included in the article's Creative Commons license, unless indicated otherwise in a credit line to the material. If material is not included 
in the article's Creative Commons license and your intended use is not permitted by statutory regulation or exceeds the permitted use, you will need to obtain permission directly from the copyright holder. To view a copy of this license, visit http://creativecommons.org/licenses/by/4.0/.

\section{REFERENCES}

Baghbani, D., The Permian Sequence in the Abadeh Region, Central Iran. Contributions to Eurasian Geology, Occasional Publ. Earth Sci. Res. Inst., Univ. South Carolina, New Ser., 1993, vol. 9A-B, pp. 7-22.

Bozorgnia, E., Microfacies and Microorganisms of Paleozoic through Tertiary Sediments of Some Part of Iran, Tehran: Natl. Iranian Oil Comp., 1964, pp. 1-22.

Bozorgnia, E., Paleozoic foraminiferal biostratigraphy of Central and East Alborz Mountains, Iran, Publ. Natl. Iranian Oil Comp., Geol. Lab., Tehran, 1973, vol. 4, pp. 1-185.

Davydov, V.I. and Arefifard, A., Middle Permian (Guadalupian) fusulinid taxonomy and biostratigraphy of the midlatitude Dalan Basin, Zagros, Iran and their applications in paleoclimate dynamics and paleogeography, GeoArabia, 2013, vol. 18, no. 2, pp. 17-62.

Huang, H., Jin, X.C., and Shi, Y.K., A Verbeekina assemblage (Permian fusulinid) from the Baoshan block in western Yunnan, China, J. Paleontol., 2015, vol. 89, pp. 269-280.

Huang, H., Jin, X.C., Shi, Y.K., Wang, H., Zheng, J., and Zong, P., Fusulinid-bearing oolites from the Tengchong Block in western Yunnan, SW China: Early Permian warming signal in the eastern peri-Gondwana, J. Asian Earth Sci., 2020, vol. 193, pp. 1-11.Jenny Deshusses, C., Le Permien de l'Elbourz Central et Oriental (Iran): Stratigraphie et micropaléontologie (foraminifères et algues), Thèse no. 2103, Univ. Genève, 1983.

Kobayashi, F. and Ishii, K.-I., Permian Fusulinaceans of the Surmaq Formation in the Abadeh Region, Central Iran, Riv. Ital. Paleontol. Stratigr., 2003, vol. 109, no. 2, pp. 307-337.

Leven, E.Ja., Stratigraphy and fusulinids of the Permian Deposits in Pamir, in Tr. GIN AN SSSR. Vyp. 167 (Trans. Geol. Inst. USSR Acad. Sci. Vol. 167), Moscow: Nauka, 1967.

Leven, E.Ja., Permian stratigraphy and Fusulinida of Afghanistan with their paleogeographic and paleotectonic implications, Geol. Soc. Am. Spec. Pap., 1997, vol. 316, pp. 1-134.
Leven, E.Ja., Origin of higher fusulinids of the order Neoschwagerinida Minato et Honjo, 1966, Stratigr. Geol. Correl., 2010, vol. 18, no. 3, pp. 290-297.

Leven, E.Ja. and Gorgij, M.N., Fusulinids and stratigraphy of the Carboniferous and Permian in Iran, Stratigr. Geol. Correl., 2011, vol. 19, no. 7, pp. 687-776.

Leven, E.Ja. and Taheri, A., Carboniferous-Permian stratigraphy and fusulinids of Eastern Iran, Gzhelian and Asselian deposits of the Ozbak-Kuh Region, Riv. Ital. Paleontol. Stratigr., 2003, vol. 109, no. 3, pp. 399-415.

Leven, E.Ja. and Vaziri Mohaddam, H., CarboniferousPermian stratigraphy and fusulinids of Eastern Iran: The Permian in the Bage-Vang Section (Shirgesht Area), Riv. Ital. Paleontol. Stratigr., 2004, vol. 110, pp. 441-465.

Lys, M., Stampfli, G., and Jenny, J., Biostratigraphie du Carbonifère et du Permien de 'E bourz oriental (an du N. E.), Notes Lab. Palèont. Univ. Genève, 1978, no. 10, pp. 63-78.

Partoazar, H., Permian deposits in Iran, Treatise Geol. Iran. Geol. Surv. Iran, 1995, vol. 22, pp. 1-370 (in Persian with English summary).

Sheng, J.C., Some fusulinids from the Maokou limestone of Chinghai Province, Northwestern China, Acta Paleont. Sinica, 1958, vol. 6, no. 3, pp. 268-291.

Sheng, J.C. and Jin, Y.G., Correlation of Permian deposits of China, Palaeoworld, 1994, vol. 4, pp. 14-113.

Stöcklin, J., Eftekhar-nezad, J., and Hushmand-zadeh, A., Geology of the Shotory Range (Tabas Area, East Iran), Rep. Geol. Surv. Iran, 1965, no. 3, pp. 1-69.

Stöcklin, J., Stratigraphic Lexicon of Iran. Part 1: Central, North, and East Iran, Rep. Geol. Surv. Iran, 1971, no. 18, pp. 1-338.

Vaziri, S.H., Lithostratigraphy and microbiostratigraphy (Foraminifera) of the Permian sequence in Northern Tehran, Central Alborz, North Iran, in The Fifth Int. Conf. Environ. Micropaleontol., Microbiol. Meiobenthol., Univ. of Madras, India, 2008, pp. 339-344.

Vaziri, S.H., Yao, A., and Kuwahara, K., Lithofacies and microbiofacies (foraminifers and radiolarians) of the Permian sequence in the Shalamzar Area, Central Alborz, North Iran, J. Geosci., Osaka City Univ., 2005, vol. 48, no. 3, pp. 39-69.

Translated by S. Nikolaeva 